\title{
Internalization of Pancasila Values in the Village Society (Research in the Administrative Village Circles of the Semarang State University Campus)
}

\author{
Masrukhi $^{1}$, AT. Sugeng Priyanto ${ }^{2}$, Margi Wahono ${ }^{3}$ \\ $\left\{\right.$ masrukhi@mail.unnes.ac.id ${ }^{1}$ \} \\ Universitas Negeri Semarang, Indonesia ${ }^{1}$ \\ Universitas Negeri Semarang, Indonesia ${ }^{2}$ \\ Universitas Negeri Semarang, Indonesia ${ }^{3}$
}

\begin{abstract}
Rural communities are people who are vulnerable to the effects of globalization. Their limited access to information from the outside community often results in shock over the values order among them. In turn, understanding, appreciation, and implementation of Pancasila in their daily lives can gradually be eroded. Many of their behaviours are no longer in accordance with the Pancasila values. If this happens protracted without any effort to strengthen the Pancasila values, undoubtedly there will be a natural silting of ideology in their daily lives. Therefore, it is necessary to identify the existing social asset among rural communities, to be revitalized to strengthen the implementation of Pancasila values among them. Pancasila Clinics among rural communities are considered to have high effectiveness in an effort to strengthen the civilization of Pancasila values.
\end{abstract}

Keywords: Internalization of Pancasila Values, Pancasila Clinic, Village Communities.

\section{Introduction}

Internalization of Pancasila values in the community is a main thing, because their lives can't be separated from globalization effects. A tendency happens where the rural communities' dynamics are quite major. The village community style can no longer be regarded as a static society and far from change. The information age that is happening now will make even a village community be able to easily access all information that even occurs worldwide. This condition will make rural communities' life experience high dynamics, not losing to urban communities. In other words, the globalization current also hits the rural communities.

Rural areas conditions which generally do not include well educated communities will experience a serious disorientation, when the offer of globalization values system approaches so swiftly, while they lack sufficient references and information about these excess values. This is a reality, given their very limited access to communication from the wider community. In people's lives everywhere, values are important things that will lead to a harmonious life. Masrukhi (2014) [1] asserted that value is interpreted as a parameter or size that underlies humans in determining their choices. That value is a measure to determine the good and bad and the right and the wrong for a social behaviour in society. The important role of value system for the community life, in the study of sociology, is to be the role of game of a living system. With the existence of the role of game the community will feel the need to be bound in it, obey all its signs, and pass it down from generation to generation, so as to create harmony together in everyday life. It can be imagined what will happen if in the life of a society it does not have a 
value parameter that is used as a reference for living together or each community group has a different value system, which between one group and another insisted that their value system is obeyed. Undoubtedly a prolonged conflict will occur and there is no way out of it.

Harmonization of community life in rural area is created because of their togetherness in upholding the principles of life values believed as the truth. Those principles of value are in the form of gotong royong (mutual cooperation), mutual respect, honesty, simplicity, mutual assistance, tepo saliro (tolerance), and the likes that have grown from generation to generation. Life values that inherently grow and develop and are held firmly by said village community, are basically the implementation of Pancasila values in daily life practice.

Pancasila value is the realization of the five principles of Pancasila. From the principle of "Belief in the One and Only God", it is determined that every Indonesian must have a god which is manifested by embracing one of the religions in Indonesia. The consequence is that Indonesian people recognize the value teachings set by God as set forth in the teachings of their religion. In this connection, the moral value system adopted by a person must not be contrary to the teachings of his religion, as a matter of fact it must be sourced from his religion. The manifestation is that all of oneself's behavior, attitudes, words and way of life must be inspired by the teachings of his religion. If not so, then it means that person does not recognize the principle of "Belief in the One and Only God".

All of the value teachings of the Pancasila principle constitute a unity, it cannot be separated between one principle's teaching with another. And Indonesian people must practice it comprehensively, not partially. The Pancasila value is the value that comes from Pancasila both in its capacity as the nation's view of life and as the basis of the state. The Pancasila value also means decency and tradition according to the Pancasila teaching. Every human deed and act according to the definition of value above, is considered moral if it is in accordance with the values, morals, and norms contained in Pancasila. The standard to determine what deed is right and good done by Indonesian people is Pancasila. In other words, Pancasila is used as a direction for all life activities and the lives of Indonesian people in all fields.

The importance of moral values in the existence of society is also expressed by Davidson and Rees-Mog [2] as follows :

"All strong societies have a strong moral basis. Any study of history of economic

development shows the close relationship between moral and economic factors.

Countries and groups that achieve successful development do so partly because they

have an ethic that encourages the economic virtues of self-reliance, hard work, family

and social responsibility, high savings, and honesty."

Pancasila has become a joint agreement and requires the Indonesian people to implement it and avoid things and behaviours that are not appropriate or conflicting. Pancasila values must refer to basic values, and could be accepted and agreed upon by the nation. Practicing the values that have been mutually agreed upon consists of two kinds: The subjective practice of Pancasila, namely the practice by individual himself, every citizen, every individual, every resident, every ruler, and every Indonesian. Objective practice, namely the practice in the form of realization in every aspect of state administration, both in the legislative, executive, and judiciary fields and all fields of statehood and especially its realization in the form of Indonesian state legislation $[3]$.

Asmaroini [4] explains that acculturation of Pancasila values which is the source of the Indonesian nation's character, means the embodiment of Pancasila values in: (1) ideas, values, norms, and regulations, (2) patterned human activities and actions, and (3) the manifestation of human creations. Acculturation of Pancasila values is not just to comprehend, but must also be internalized and manifested as experience by each individual and all levels of society so as to 
raise awareness and necessity, sharpen feelings, increase endurance, deterrence and competitiveness of the nation which are all reflected in the community's responsiveness and behaviour. Acculturation of Pancasila's noble values needs to be pursued in various community groups, both professional groups such as labour, notaries, teachers and lawyers, and also functional groups such as women, youth, etc.

Pancasila culture which in this case is meant as the life order that is imbued with Pancasila values, and therefore attitudes, behaviors, and habits that are carried out by the community in daily life are always based on Pancasila values. The Pancasila values that shape the culture of Pancasila are of course very broad. However, in this study a simplification was carried out, that the values in question were the values of devotion, the value of social participation, the value of democracy, the value of gotong royong(mutual cooperation), the value of responsibility, the value of patriotism, and the value of caring for others. Communities around the campus of Universitas Negeri Semarang, are rural communities. The people's lives in Sekaran, Patemon, Pakintelan, Sukorejo, and Kalisegoro (abbreviated Seppasuka) always interact and communicate directly with the existence of the UNNES campus, especially with students who live in these five administrative villages.

The occurring symptoms in rural communities regarding the excesses of globalization, also occur in these five urban communities. Moreover, the presence of the Unnes campus with so many students coming from various regions, will quickly affect the lifestyle and value system of the Seppasuka community. Through one of the conservation pillars of Universitas Negeri Semarang, namely the cultural conservation pillar, there are things that need to be considered, namely how to carry out conservation efforts of cultural values of the Seppasuka community so that they continue to uphold the principles of value systems that grow from generation to generation, which are in harmony with the Pancasila value system.

This article discusses issues regarding the implementation of the Pancasila culture in the daily lives of villagers, the factors that hinder the implementation of the Pancasila cultural values, identify social asset in the community, and the model development of the Pancasila Clinic that is compatible with the village community life.

\section{Research Method}

Internalization of Pancasila values in the community is a main thing, because their lives can't be separated from globalization effects. A tendency happens where the rural communities' dynamics are quite major. The village community style can no longer be regarded as a static society and far from change. The information age that is happening now will make even a village community be able to easily access all information that even occurs worldwide. This condition will make rural communities' life experience high dynamics, not losing to urban communities. In other words, the globalization current also hits the rural communities.

Rural areas conditions which generally do not include well educated communities will experience a serious disorientation, when the offer of globalization values system approaches so swiftly, while they lack sufficient references and information about these excess values. This is a reality, given their very limited access to communication from the wider community. In people's lives everywhere, values are important things that will lead to a harmonious life. Masrukhi [1] asserted that value is interpreted as a parameter or size that underlies humans in determining their choices. That value is a measure to determine the good and bad and the right and the wrong for a social behaviour in society. The important role of value system for the 
community life, in the study of sociology, is to be the role of game of a living system. With the existence of the role of game the community will feel the need to be bound in it, obey all its signs, and pass it down from generation to generation, so as to create harmony together in everyday life. It can be imagined what will happen if in the life of a society it does not have a value parameter that is used as a reference for living together or each community group has a different value system, which between one group and another insisted that their value system is obeyed. Undoubtedly a prolonged conflict will occur and there is no way out of it.

Harmonization of community life in rural area is created because of their togetherness in upholding the principles of life values believed as the truth. Those principles of value are in the form of gotong royong (mutual cooperation), mutual respect, honesty, simplicity, mutual assistance, tepo saliro (tolerance), and the likes that have grown from generation to generation. Life values that inherently grow and develop and are held firmly by said village community, are basically the implementation of Pancasila values in daily life practice.

Pancasila value is the realization of the five principles of Pancasila. From the principle of "Belief in the One and Only God", it is determined that every Indonesian must have a god which is manifested by embracing one of the religions in Indonesia. The consequence is that Indonesian people recognize the value teachings set by God as set forth in the teachings of their religion. In this connection, the moral value system adopted by a person must not be contrary to the teachings of his religion, as a matter of fact it must be sourced from his religion. The manifestation is that all of oneself's behavior, attitudes, words and way of life must be inspired by the teachings of his religion. If not so, then it means that person does not recognize the principle of "Belief in the One and Only God".

All of the value teachings of the Pancasila principle constitute a unity, it cannot be separated between one principle's teaching with another. And Indonesian people must practice it comprehensively, not partially. The Pancasila value is the value that comes from Pancasila both in its capacity as the nation's view of life and as the basis of the state. The Pancasila value also means decency and tradition according to the Pancasila teaching. Every human deed and act according to the definition of value above, is considered moral if it is in accordance with the values, morals, and norms contained in Pancasila. The standard to determine what deed is right and good done by Indonesian people is Pancasila. In other words, Pancasila is used as a direction for all life activities and the lives of Indonesian people in all fields.

The importance of moral values in the existence of society is also expressed by Davidson and Rees-Mog (1997: 176) [2] as follows :

"All strong societies have a strong moral basis. Any study of history of economic development shows the close relationship between moral and economic factors. Countries and groups that achieve successful development do so partly because they have an ethic that encourages the economic virtues of self-reliance, hard work, family and social responsibility, high savings, and honesty."

Pancasila has become a joint agreement and requires the Indonesian people to implement it and avoid things and behaviours that are not appropriate or conflicting. Pancasila values must refer to basic values, and could be accepted and agreed upon by the nation. Practicing the values that have been mutually agreed upon consists of two kinds: The subjective practice of Pancasila, namely the practice by individual himself, every citizen, every individual, every resident, every ruler, and every Indonesian. Objective practice, namely the practice in the form of realization in every aspect of state administration, both in the legislative, executive, and judiciary fields and all fields of statehood and especially its realization in the form of Indonesian state legislation $[3]$. 
Asmaroini [4] explains that acculturation of Pancasila values which is the source of the Indonesian nation's character, means the embodiment of Pancasila values in: (1) ideas, values, norms, and regulations, (2) patterned human activities and actions, and (3) the manifestation of human creations. Acculturation of Pancasila values is not just to comprehend, but must also be internalized and manifested as experience by each individual and all levels of society so as to raise awareness and necessity, sharpen feelings, increase endurance, deterrence and competitiveness of the nation which are all reflected in the community's responsiveness and behaviour. Acculturation of Pancasila's noble values needs to be pursued in various community groups, both professional groups such as labour, notaries, teachers and lawyers, and also functional groups such as women, youth, etc.

Pancasila culture which in this case is meant as the life order that is imbued with Pancasila values, and therefore attitudes, behaviors, and habits that are carried out by the community in daily life are always based on Pancasila values. The Pancasila values that shape the culture of Pancasila are of course very broad. However, in this study a simplification was carried out, that the values in question were the values of devotion, the value of social participation, the value of democracy, the value of gotong royong(mutual cooperation), the value of responsibility, the value of patriotism, and the value of caring for others. Communities around the campus of Universitas Negeri Semarang, are rural communities. The people's lives in Sekaran, Patemon, Pakintelan, Sukorejo, and Kalisegoro (abbreviated Seppasuka) always interact and communicate directly with the existence of the UNNES campus, especially with students who live in these five administrative villages.

The occurring symptoms in rural communities regarding the excesses of globalization, also occur in these five urban communities. Moreover, the presence of the Unnes campus with so many students coming from various regions, will quickly affect the lifestyle and value system of the Seppasuka community. Through one of the conservation pillars of Universitas Negeri Semarang, namely the cultural conservation pillar, there are things that need to be considered, namely how to carry out conservation efforts of cultural values of the Seppasuka community so that they continue to uphold the principles of value systems that grow from generation to generation, which are in harmony with the Pancasila value system.

This article discusses issues regarding the implementation of the Pancasila culture in the daily lives of villagers, the factors that hinder the implementation of the Pancasila cultural values, identify social asset in the community, and the model development of the Pancasila Clinic that is compatible with the village community life.

\section{Result and Discussion}

As the basis of morality and social, national, and state direction, Pancasila has a strong ontological, epistemological, and axiological foundation. Each principle have a justification of historicality, rationality, and actuality, which if understood, lived, believed, and consistently practiced could sustain the great achievements of the nation's civilization [6]. This is the fundamental argument for the need to re-actualize Pancasila values and contextualization of Pancasila values in building aspired societies, both in the position of the Pancasila as a view of life, personality, national ideology, and state foundation.

Pancasila as the nation's view of life is used as a guide in the daily lives of Indonesian people both in terms of attitudes and behaviours that must always be imbued with Pancasila's noble values. This is very important because by applying Pancasila's noble values in everyday life then a harmonious life order among the people can be realized. To be able to realize all that the 
citizens cannot live alone, they must continue to establish relationships in positive-constructive communication and interaction. In this way, the individual way of life can adapt to the group way of life in the community.

Through the process of communication-interaction between citizens, the internalization process of Pancasila values can occur. Internalization here can be interpreted as accepting, supporting, and committing to implementing the values and norms contained in Pancasila. The internalization process occurs when there are dialogue, togetherness, and exemplary among the citizens to find solutions to the problems they faced together. Dialogue, togetherness, and exemplary happens when citizens observe, explore, analyze, and look for and find alternatives to solving everyday problems. The intensity of residents' discussion in the family environment, neighborhood units, community units, and existing social communities continues to be improved. This process is expected to build a community that is aware of and belief in the truth and efficacy of Pancasila values.

The Pancasila-aware community, which is able to think critically, borrow the formulas used by Ennis [7], which has the following indicators: 1) able to state the main points of the problem: find clear answers to each problem; 2) able to uncover the facts needed in solving problems; 3 ) able to choose logical, relevant, and accurate arguments; 4) able to find alternatives, seek as many explanations as possible, and take positions when there is sufficient evidence; and 5) able to determine the consequences of an alternative taken to determine a decision. Such a society is often referred to as a civil society.

The problem in acculturating Pancasila is too grandiose words, but too little action. This is what was stated by Yudi Latif (2017) [8], that there are many doubts about Pancasila's sacredness in the reality of daily life. Therefore, an effort must be done to preach and prioritize exemplary stories in practicing Pancasila values. Such exemplary stories exist in all levels of society, including in villages or administrative village or even in the family. These exemplary stories become references, inspiration, and mold in the struggle, dialogue, and debate in solving everyday problems in society.

Pancasila Clinic is an alternative solution offered in this study. The Pancasila Clinic in question is an educational activity among the village community, the implementation of which is adjusted to the characteristics of the village community. The activities were carried out around their place of residence by taking activities at night, and the content of the materials, methods, and media were adjusted to their level of thinking. One thing that becomes the standard of the Pancasila Clinic activities was the building of understanding and appreciation of the community around the Seppasuka administrative village on the values of Pancasila, to then at the same time implement the Pancasila values in the daily life of the village community.

The Pancasila Clinic was organized based on the character hermitage of the UNNES Political and Citizenship Education Department, with full support from the research team and in collaboration with community leaders and religious leaders around the Seppasuka community. In the implementation, the research team got a lot of important information regarding the implementation of Pancasila values in the community and the practice of community, nation, and state life in the communities around the area of Sekaran, Patemon, Pakintelan, Sukorejo, and Kalisegoro. Information obtained from the public was immediately accepted and accommodated to provide answer that are able to provide solutions or solve problems.

The implementation of the Pancasila values of villagers will be manifested in their ability to play a proactive role as citizens and community members, which is reflected in the daily life order. The village community is a society with a simple mindset and behavior patterns. This simplicity is due to their limited access to outside world information in a sense of it is outside 
their lives. This is in line with programs run by the government in order to empower the community in understanding and implementing Pancasila in their daily lives. They will show performance as citizens who in daily life are imbued with God's values, human values, nationality, democracy, and social care. Thus photographing the implementation of Pancasila values in community life, cannot be done partially, but rather a unity of values from the first principle to the fifth principle, with stages starting from the understanding of Pancasila values, the appreciation of Pancasila values, and ending with practicing the values of Pancasila in everyday life.

The implementation performance of the Pancasila values among the village community which became the research base can be described as follows.

\begin{tabular}{|c|c|c|c|c|c|}
\hline No. & Scope & Principle & Score & Categories & Explanation \\
\hline \multirow[t]{7}{*}{1.} & Comprehension & First Principle & 72,67 & High & \\
\hline & & Second & 63,40 & Medium & \\
\hline & & Principle & & & \\
\hline & & Third Principle & 50,40 & Low & \\
\hline & & Fourth & 50,00 & Low & \\
\hline & & Principle & & & \\
\hline & & Fifth Principle & 49,00 & Low & \\
\hline \multirow[t]{7}{*}{2.} & Internalization & First Principle & 60,00 & Medium & \\
\hline & & Second & 65,00 & Medium & \\
\hline & & Principle & & & \\
\hline & & Third Principle & 50,00 & Low & \\
\hline & & Fourth & 52,60 & Low & \\
\hline & & Principle & & & \\
\hline & & Fifth Principle & 49,00 & Low & \\
\hline \multirow[t]{7}{*}{3.} & Practice & First Principle & 90,00 & Very High & \\
\hline & & Second & 86,45 & Very High & \\
\hline & & Principle & & & \\
\hline & & Third Principle & 85,00 & High & \\
\hline & & Fourth & 85,00 & High & \\
\hline & & Principle & & & \\
\hline & & Fifth Principle & 60,00 & Medium & \\
\hline
\end{tabular}

$\begin{array}{lll}\text { Notes: } & 20-36 & \text { Very Low } \\ & 37-53 & \text { Low } \\ & 54-70 & \text { Medium } \\ & 71-86 & \text { High } \\ & 87-100 & \text { Very High }\end{array}$

Research findings regarding the implementation of the Pancasila values among villagers, as explained above showed that in general their understanding of the Pancasila values was low, especially the third, fourth and fifth principle. Only in the comprehension of the first value that had a high level. This was reasonable considering that generally rural communities are religious, and the first principle is related to religious life. While the understanding of human values was medium. This was related to the habits of villagers who have a high level of kinship with fellow villagers.

While in the realm of internalization of the Pancasila values, the research findings showed medium and low levels. In the appreciation of the values of the first and second principles of 
Pancasila were of moderate level, the internalization of the values of the third, the fourth, and the fifth principles were at low levels. The lack of comprehension and internalization of rural communities towards the values of Pancasila was actually more due to limited access to information about Pancasila. Their busy routine with their work as farmers, does not allow them to interact intensely with information around the Pancasila values. Likewise, social interaction was very limited, which occurred only between their fellow farmers and village communities, making the spectrum of their talks and discussions limited to their daily lives.

Thus their low comprehension and internalization of Pancasila values was not caused by low levels of nationality, but rather due to the limited access to information and social interaction networks between them. This was evidenced by the implementation scope of Pancasila values revealed in this study. The table above showed that in the realm of implementing Pancasila values, the levels were in the very high and high categories. In the practice of the first and second principle values were very high, and in the practice of the third, fourth, and fifth principles levels were high. This implied that in practice they have implemented the Pancasila values in their daily lives. The problem then is how to strengthen the comprehension and internalization of the village community on the Pancasila values. These two realms are important considering that authentic practice of a value will occur when it is based on a good comprehension and internalization of the value system.

From the chart above, it can be seen that the development of the Pancasila clinic stems from studies conducted by Political and Citizenship Education Department through character hermitage, related to the problems that arise regarding the implementation of Pancasila values occured in the life of society, nation, and state in the communities of Sekaran, Pakintelan, Patemon, Sukorejo, and Kalisegoro (Seppasuka) such as the low comprehension of the Pancasila values, the low internalization of Pancasila values from the community, as well as high external influences.

\section{Conclusion}

Pancasila internalization developed by researchers was to go directly to the source or location where the community lives and runs daily activities. Researchers conducted dialogue with the community and its leaders about the problems that occur in society related to the practice of the values of Pancasila. The next step taken by the research team was to discuss issues in the character hermitage of political and citizenship education major for further study with experts. After an in-depth study and a solution to the problems of practicing Pancasila in the community was obtained, the research team returned to the community to present solutions to the problems they experienced.

In the future, the internalization of Pancasila will be intensified by collaborating with the character hermitage and study center (P3KB) of UNNES Political and Citizenship Education Department. Pancasila Clinic will be more intensive in providing Pancasila education to the community around the campus environment, providing solutions to problems faced by the community related to the implementation of Pancasila values, and together with the community making Pancasila a way of life for all Indonesian people. The intensity of residents' discussion in the family environment, neighborhood units, community units, and existing social communities continues to be improved. 


\section{References}

[1] Masrukhi, Nilai dan Moral, sebuah Diskursus. Yogyakarta: Penerbit K Media, 2014.

[2] J. Hutchinson, "Moral innovators and the politics of regeneration: the distinctive role of cultural nationalists in nation-building," Int. J. Comp. Sociol., vol. 33, no. 1, p. 101, 1992.

[3] M. S. Kaelan, "Filsafat Pancasila Pandangan Hidup Bangsa Indonesia," Yogyakarta, Paradig. Yogyakarta, 2002.

[4] A. P. Asmaroini, "Menjaga Eksistensi Pancasila Dan Penerapanya Bagi Masyarakat di Era Globalisasi,” JPK J. Pancasila dan Kewarganegaraan, vol. 1, no. 2, pp. 50-64, 2017.

[5] L. J. Moleong, Metode Penelitian Kualitatif. Jakarta: Penerbit Gramedia, 2000.

[6] Y. Latif, "Negara Paripurna," Gramedia Pustaka Utama, Jakarta, 2015.

[7] R. Amal, "Keterampilan Berpikir Kritin Menurut Ennis," 2017. [Online]. Available: https://www.academia.edu/6523353/Keterampilan_berpikir_kritis_menurut_ennis. [Accessed: 26-Dec-2017].

[8] Y. Latif, Mata air keteladanan: Pancasila dalam perbuatan. Mizan, 2017. 